\title{
Editorial: Proceedings of the 21st Biennial Southern Silvicultural Research Conference
}

\author{
John L. Willis ${ }^{1 *}$ and Thomas J. Dean ${ }^{2}$ \\ 'Southern Research Station, United States Department of Agriculture (USDA) Forest Service, Auburn, AL, United States, \\ ${ }^{2}$ School of Renewable Natural Resources, Louisiana State University Agricultural Center, Baton Rouge, LA, United States
}

Keywords: silviculture, forest management, prescribed fire, functional ecology, forest ecology

\section{Editorial on the Research Topic}

\section{Proceedings of the 21st Biennial Southern Silvicultural Research Conference}

\section{OPEN ACCESS}

Edited and reviewed by: Manfred J. Lexer,

University of Natural Resources and Life Sciences Vienna, Austria

${ }^{*}$ Correspondence: John L. Willis john.willis@usda.gov

Specialty section: This article was submitted to

Forest Management, a section of the journal Frontiers in Forests and Global

Change

Received: 22 December 2021

Accepted: 12 January 2022

Published: 01 February 2022

Citation:

Willis JL and Dean TJ (2022) Editorial:

Proceedings of the 21st Biennial

Southern Silvicultural Research

Conference.

Front. For. Glob. Change 5:841502. doi: 10.3389/ffgc.2022.841502
The Proceedings of the 21st Biennial Southern Silviculture Research Conference provides a collection of seven studies identifying a variety of factors influencing stand dynamics in the southeastern United States. While forest management was the central theme of this Research Topic, the studies within derive from a diverse set of biological disciplines including silviculture, fire ecology, plant physiology, functional ecology, forest ecology, plant physiology, and forest genetics. Moreover, the body of research presented in this Research Topic can help inform management decisions on broad conservation issues including forest tree improvement, bioenergy plantation establishment, longleaf pine conservation, prescribed fire efficacy, and invasive species impacts on native vegetation.

\section{AUTHOR CONTRIBUTIONS}

All authors listed have made a substantial, direct, and intellectual contribution to the work and approved it for publication.

Conflict of Interest: The authors declare that the research was conducted in the absence of any commercial or financial relationships that could be construed as a potential conflict of interest.

Publisher's Note: All claims expressed in this article are solely those of the authors and do not necessarily represent those of their affiliated organizations, or those of the publisher, the editors and the reviewers. Any product that may be evaluated in this article, or claim that may be made by its manufacturer, is not guaranteed or endorsed by the publisher.

Copyright (c) 2022 Willis and Dean. This is an open-access article distributed under the terms of the Creative Commons Attribution License (CC BY). The use, distribution or reproduction in other forums is permitted, provided the original author(s) and the copyright owner(s) are credited and that the original publication in this journal is cited, in accordance with accepted academic practice. No use, distribution or reproduction is permitted which does not comply with these terms. 